\title{
Stable carbon isotope proxies for the development of unconventional petroleum reservoirs and the protection of groundwater resources
}

\author{
JAIME CESAR ${ }^{1 *}$, JAMES WOOD ${ }^{2}$, PAULINE HUMEZ ${ }^{1}$, \\ Michael Nightingale ${ }^{1}$, VeITH BeCKeR ${ }^{1}$, OMID \\ ARDAKANI $^{3}$, BERNHARD MAYER ${ }^{1}$ \\ ${ }^{1}$ Applied Geochemistry Group. University of Calgary, \\ Calgary, Alberta T2N 1N4, Canada \\ (*correspondance: jaimerafael.cesarcol@ucalgary.ca) \\ ${ }^{2}$ Calaber1 Resources, Calgary, Alberta T3H 3R3, Canada \\ ${ }^{3}$ Geological Survey of Canada, Natural Resources Canada, \\ Calgary, Alberta T2L 2A7, Canada
}

Hydrocarbons from low-permeability reservoirs represent significant assests for energy provision in Canada and worldwide, and geochemistry is fundamental in assessing exploration and production of petroleum fluids from these unconventional systems. Stable isotope analysis of gaseous hydrocarbons $\left(\mathrm{C}_{1}-\mathrm{C}_{4}\right)$ continues to gain interest for its potential applications in (i) fingerprinting producing intervals, (ii) quantifying commigled production, and (iii) detecting thermogenic gas migration through tight reservoirs and potentially into shallow aquifers. Application of stable isotope geochemistry in such settings requires an approach that is unique to the generation of hydrocarbons in tight rocks without significant primary migration (closed systems). A challenge to this approach is the occurrence of hybrid reservoirs such as the siltstone-dominated Montney Formation, western Canada, where some of the hydrocarbon accumulations formed in conventional ways (open systems) and migrated some distance. Indeed gas migration is a common feature of this play [1] and impacts the economic development of hydrocarbons. In this study we describe novel carbon isotope distribution models and test how applicable they can be to accurately estimate thermal maturity and identify fluid migration and mixing in a tight play like the Montney Formation, at a semi-regional scale. Furthermore, we test the applicability of these isotope proxies for the characterization of hydrocarbon gases in shallow aquifers located above the unconventional resource play, and we compare the outcome with inorganic geochemical tools previously defined [2].

References

[1] Wood \& Sanei (2016), Nature Communications 7(13614), 1-9

[2] Humez, Osselin, Kloppmann \& Mayer (2019), Journal of

Contaminant Hydrology 226, 103525 